\title{
Effects of Hypoxia on the Behaviour, Mortality and Plasma Electrolyte Concentrations of Goldlined Seabream, Rhabdosargus sarba
}

\author{
Hamed M. Al-Gheilani ${ }^{* 1}$, Colin Waring ${ }^{2}$, Abdulaziz Al-Kindi ${ }^{3}$ \\ and Shehla Amer ${ }^{4}$ \\ ${ }^{1}$ Marine Science and Fisheries Centre, P.O. Box 227, \\ PC 100, Muscat, Sultanate of Oman \\ ${ }^{2}$ Marine Institute, Portsmouth University, UK \\ ${ }^{3}$ Department of Biology, College of Science, \\ Sultan Qaboos University, Sultanate of Oman \\ ${ }^{4}$ Nizwa University, Sultanate of Oman \\ تأثثر نقص الأكسجين على سلوك ونسبة الوفيات

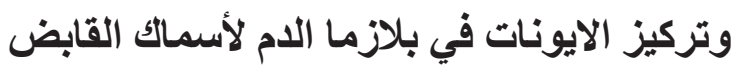

حمد بن محمد الغيلاني ، كولن ويرنج، عبد العزيز بن يحيى الكندي وشهلا عامر

الخلاصة: تمت در اسة أثر نقص الأكسجين على سلوك ونسبة الوفيات وتركيز الايونات في بلازما الدم لأسماك القابض في المختبر

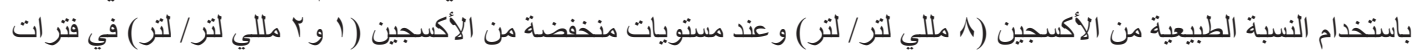

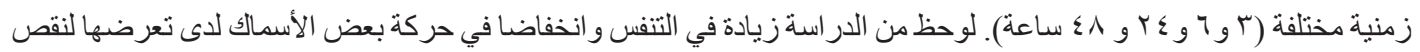

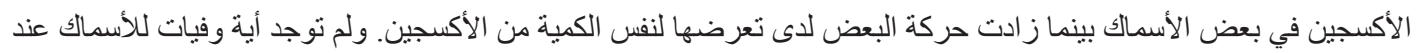

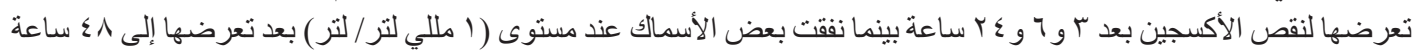

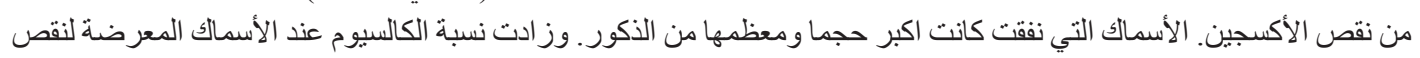

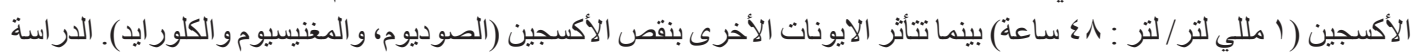

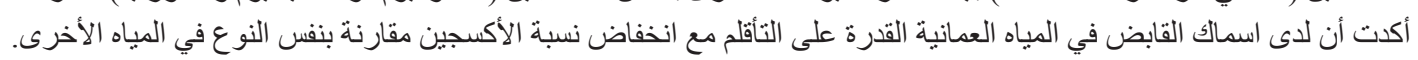

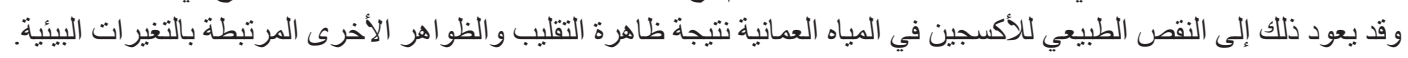

ABSTRACT: The behaviour, mortality rates and plasma electrolyte concentrations of goldlined seabream Rhabdosargus sarba challenged with low dissolved oxygen (DO) conditions was studied in an experimental setup, comprising a control (7.9 ml/1 DO) and two hypoxic ( $2 \mathrm{ml} / 1$ and $1 \mathrm{ml} / 1$ DO) treatments. Increased ventilation rates and decreased swimming activity were observed in hypoxic treatments, but some fish exhibited strenuous avoidance actions. No mortalities were observed after $3 \mathrm{~h}, 6$ $\mathrm{h}$, or $24 \mathrm{~h}$, but $50 \%$ of males and $18 \%$ of females died in the $48 \mathrm{~h}$ treatment at $1 \mathrm{ml} / 1 \mathrm{DO}$. The mean size of surviving fish (305 $\pm 32.1 \mathrm{~g}$ total weight) was significantly smaller than those that died $(425 \pm 33.1 \mathrm{~g})$. The plasma concentrations of $\mathrm{Na}^{+}, \mathrm{Cl}^{-}$and $\mathrm{Mg}^{2+}$ did not vary significantly relative to treatment, exposure time, fish size and gender, or interactions among treatment, time and gender. $\mathrm{Ca}^{2+}$ concentrations increased significantly after $48 \mathrm{~h}$ at $1 \mathrm{ml} / 1$, but this result may be artificial because of the small sample size. The results suggest that $R$. sarba is comparatively tolerant of the low oxygen or hypoxic conditions that often occur in the coastal waters of Oman, where seasonal upwellings and high primary productivity have in the past caused mass mortalities of demersal fishes.

Keywords: Behaviour, mortality, hypoxia, electrolytes, goldlined seabream.

*Corresponding author. E-mail: asadalaqidah@hotmail.com 


\section{Introduction}

Fish challenged with reduced levels of dissolved oxygen (DO), can respond by moving away (vertical or horizontal habitat changes) or by changing activity patterns to increase ventilation surfaces or decrease energy demands (Kramer, 1987; Dalla Via et al., 1998). Increases in ventilation frequency have been reported in numerous species (Holeton and Randall, 1967; Soivio et al., 1980; Soivio et al., 1981; Woo and $\mathrm{Wu}, 1984$; Thomas et al., 1988; Brauner and Randall, 1998; Maxime et al., 2000; Pichavant et al., 2002; Timmerman and Chapman, 2004; Evans et al., 2005), as have increases in ventilation volume (Smith and Jones, 1982; Randall, 1990). The result is an increased oxygen uptake and enhanced convective conditions for $\mathrm{CO}_{2}$ removal (Brauner and Randall, 1998). Van Raaij et al., (1996a) reported on behavioural strategies of surviving and non-surviving fish during confined hypoxia exposure. Non-surviving fish exhibited strenuous avoidance (or escape) reactions, and were not able to maintain homeostasis, as evidenced by elevated plasma ions, metabolic rate and stress hormones compared to the less active surviving fish. Elevations in plasma ion (electrolyte) levels in response to physical disturbances such as net confinement and transport have been documented for several marine teleosts (Fletcher, 1975; Pawson and Lockwood, 1980; Soivio et al., 1980; Robenston et al., 1987; Waring et al., 1992; Waring et al., 1996). Below a species-dependent critical oxygen threshold, aerobic energy production decreases and fish mainly resort to anaerobic metabolism (Dalla Via et al., 1994) and sometimes metabolic depression (van Waversveld et al., 1989). Most of these mechanisms are under hormonal control involving catecholamines and cortisol (Kinkead and Perry, 1991; Van Raaij et al., 1996b; Pichavant et al., 2002; Perry et al., 2004).

Localized or extensive low oxygen or hypoxic conditions are common in the coastal waters of Oman (REF), where seasonal upwellings of nutrient-rich and oxygen-depleted waters are driven by the summer monsoon winds. These upwellings give rise to algal blooms in the photic zone bloom collapse, bacterial decomposition and settlement on the seafloor results in an oxygen-depleted bottom-water layer below the thermocline (Claereboudt et al., 2001). Although generally beneficial to fisheries, phytoplankton blooms can trigger harmful algal blooms (HABs or red tides), and the latter have been implicated in massive fish mortalities in both the Gulf of Oman (Claereboudt et al., 2001) and the Arabian Sea (Al-Busaidi et al., this issue). These mortalities were attributed to asphyxia or toxins. A recent review of $\mathrm{HAB}$ occurrences between 1976 and 2004 showed 66 red tide events in the coastal waters of Oman, out of which 25 resulted in mass mortalities of fish and other organisms (Al-Gheilani et al., to be submitted).

The importance of commercial fishing to Oman and increasing likelihood of low-oxygen conditions stimulated a recent $\mathrm{PhD}$ study on the physiology of goldlined seabream Rhabdosargus sarba confronted with hypoxic conditions (Al Gheilani, 2007). Goldlined seabream is a coastal species distributed throughout the Western Indian Ocean, including the Red Sea and Arabian Gulf (Randall, 1995). It is often encountered in small schools, reaches a maximum size of $60 \mathrm{~cm}$, and feeds on bivalve molluscs, sand dollars, sea urchins and sand-dwelling crustaceans (Randall, 1995). It forms part of the demersal fish assemblage of Oman, which is heavily fished.

The aims of this study were to examine the effects of low oxygen conditions on the behaviour, mortality rates and electrolyte balance of $R$. sarba under controlled laboratory conditions. Particular attention was given to the influence of gender and body size on the above parameters.

\section{Materials and Methods}

Trap-caught goldlined seabream with an average weight of $245.9 \pm 8.6 \mathrm{~g}$ and length of $23.5 \pm 1.4 \mathrm{~mm}$ were purchased from a local fisherman in Muscat $\left(24 \mathrm{~N}^{\circ} 58 \mathrm{E}^{\circ}\right)$. Fish were kept in oxygenated seawater while on board and transferred to well-aerated tanks on land where the water temperature and salinity were kept at $21-24^{\circ} \mathrm{C}$ and $20-25 \mathrm{psu}$. Fish were acclimatized for a total of 3 weeks during which they were fed once daily (Plante, et al., 1998) with commercially-prepared fish pellets (Arasco, Saudi Arabia).

The continuous flow experimental setup consisted of three seawater reservoirs: an overhead 600 litre (1) tank, fully aerated 4001 fish acclimatization tank and a 4001 water circulation tank (see Fig. 1). The circulation tank was connected to 8 experimental tanks ( $30 \times 60 \times 40 \mathrm{~cm} ; 45 \mathrm{l}$; glass with 2 ports), with flow rates of $1.51 . \mathrm{min}^{-1}$ and water circulating through a biological filter and UV sterilizer (temperature, $22.9 \pm 0.1 \mathrm{C}^{\circ}$; salinity $34.8 \pm 0.8 \mathrm{psu}$; ammonia, $2.01 \pm 0.6$ $\mu \mathrm{m} / 1$; nitrite $0.23 \pm 0.04 \mu \mathrm{m} / \mathrm{l}$; phosphate $0.5 \pm 0.01$ 


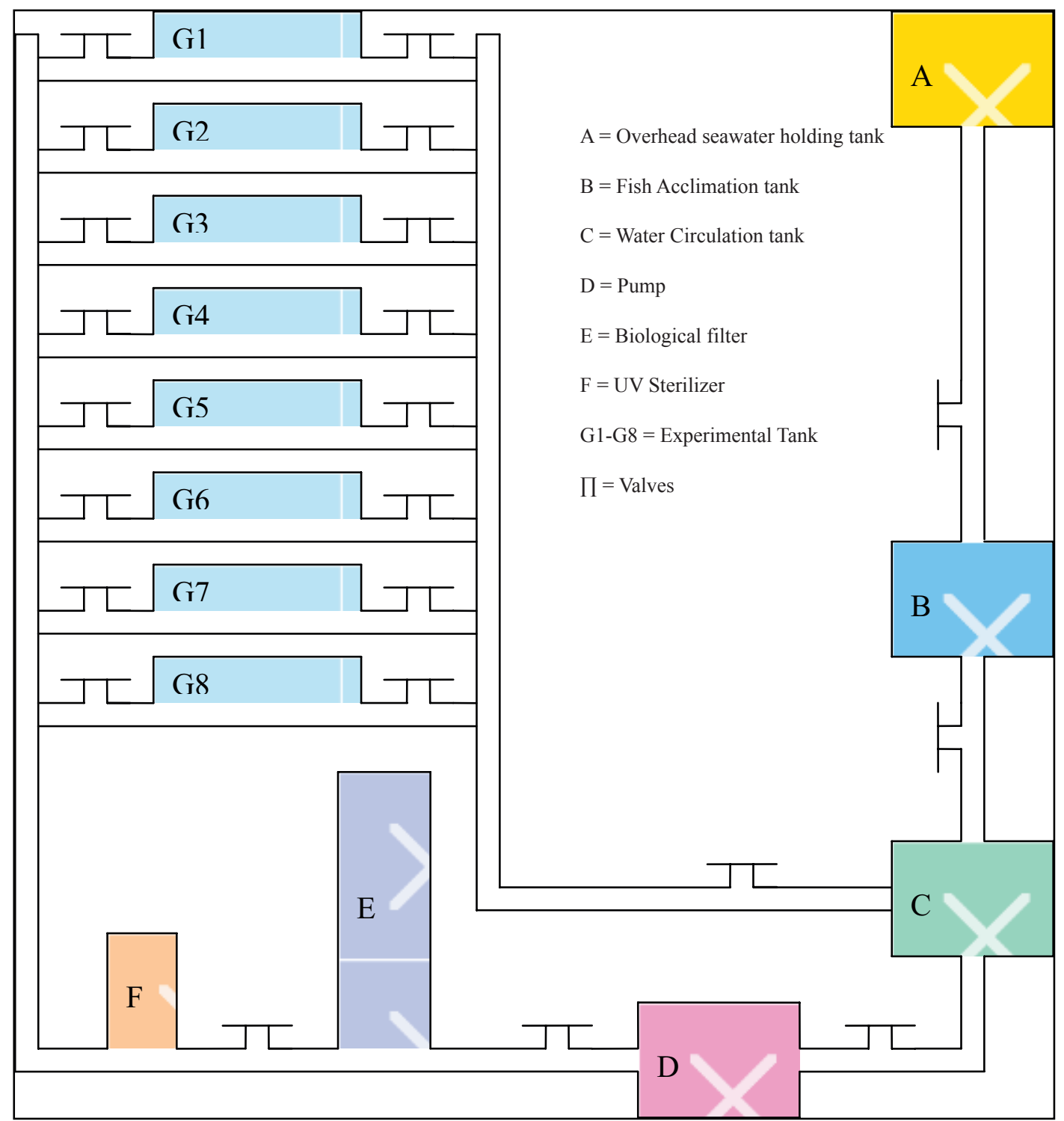

Figure 1. Arrangement of seawater holding and experiment tanks.

$\mu \mathrm{m} / \mathrm{l}$; and a $12 \mathrm{~L}: 12 \mathrm{D}$ photoperiod). The sides of the experimental tanks were covered with black paper to minimize disturbances to fish.

An Aqua Traul Oxygen Monitoring and Control System (Dryden Aqua, Scotland, UK.), fitted with 8 oxygen probes (Dryden Aqua, Scotland, U.K.) was connected to solenoid valves to regulate the oxygen and nitrogen input to the 8 experimental tanks. The Aqua Traul network communicates via RS 485 serial
BUS protocol with a standard PC and was configured using Aqua Traul Software.

Feeding was stopped and fish transferred from the acclimatization to the experimental tanks (fully aerated seawater; $7.9 \pm 0.7 \mathrm{ml}^{-1^{-1}} \mathrm{O}_{2}$ or $100 \%$ saturation) $24 \mathrm{~h}$ before low oxygen trials (see Lapner and Perry, 2001). Two levels of hypoxia, $2.0 \pm 0.9 \mathrm{ml}^{-1} \mathrm{l}^{-1} \mathrm{O}_{2}(2.8 \mathrm{mg} / \mathrm{l}$ or $25 \%$ saturation) and $1.1 \pm 0.2 \mathrm{ml} . \mathrm{l}^{-1}(1.4 \mathrm{mg} / \mathrm{l}$ or $12.5 \%$ saturation) were selected for trials and control fish were 
maintained at $7.9 \pm 0.7 \mathrm{ml}^{11^{-1}} \mathrm{O}_{2}$. Oxygen and nitrogen were purged from tanks by immersing flexible tygon tubing (ID $4 \mathrm{~mm}$, OD $1.2 \mathrm{~cm}$ ) attached to ceramic gas diffusers (Dryden Aqua, Scotland, U.K.), and oxygen levels adjusted manually and via the PC by bubbling pure nitrogen / oxygen into tanks from respective cylinders. The time required to adjust the DO level was 10-20 minutes. Once set up, the Aqua Traul units continued to monitor the system, automatically opening and closing the solenoid valves to regulate the flow of oxygen and nitrogen. Water samples (250 $\mathrm{ml}$ ) were collected using Niskin bottles for analysis of ammonia, nitrite and phosphorus. Nutrients were measured using a 5-channel SKALAR Flow Access auto-analyzer (see Strickland and Parsons, 1972).

Fish behaviour during hypoxia exposure and time of death was monitored every 2-4 hours. After $3 \mathrm{~h}, 6 \mathrm{~h}, 24 \mathrm{~h}$ and $48 \mathrm{~h}$ individual fish in experimental tanks were netted, stunned by a blow to the head, and terminal blood samples taken. The sex, total weight (TW, g) and total length (TL, cm) were determined. The TW and TL of surviving fish were compared with those that died using Student's t-test.

Whole blood was allowed to clot at room temperature for $30 \mathrm{~min}$ and centrifuged at $11000 \mathrm{rpm}$ for $5 \mathrm{~min}$ to obtain plasma (Hishida et al., 1999). All plasma samples were immediately frozen at $-80 \mathrm{C}^{\circ}$. The Beckman Synchron CX7 System (CX3 module) was used to determine plasma electrolytes. Sodium and chloride concentrations were determined by measuring electrolyte ion activity in solution.
Magnesium concentrations were determined using the manufacturers reagent and a colourimetric timed-endpoint method. The calcium concentrations were determined by adding Arsenazo III calcium reagent and measuring the absorbance of the resulting coloured calcium-Arsenazo III complex at $650 \mathrm{~nm}$ and $700 \mathrm{~nm}$.

The effects on plasma ion concentrations of the variables for gender, exposure time $(3 \mathrm{~h}$, $6 \mathrm{~h}, 24 \mathrm{~h}$ and $48 \mathrm{~h}$ ), treatment (control, $1 \mathrm{ml} / \mathrm{l}$ or $2 \mathrm{ml} / \mathrm{l} \mathrm{DO}$ ), TL and TW, and the interactions of treatment $\times$ time, treatment $\times$ gender, time $\times$ gender and treatment $\times$ time $\times$ gender were analysed using a General Linear Model (GLM) with gender and body size (cm and $\mathrm{g}$ ) as factors, accepting $P \leq 0.05$ as significant (REF). Statistical analysis was carried out using Minitab.

\section{Results}

All fish survived up to $48 \mathrm{~h}$ in the $2 \mathrm{ml} / \mathrm{l} \mathrm{DO}$ trials. In the $1 \mathrm{ml} / 1 \mathrm{DO}$ trials, all fish exposed for $3 \mathrm{~h}, 6 \mathrm{~h}$ and 24 hours survived, but $50 \%$ of males $(n=12)$ and $18 \%$ of females $(\mathrm{n}=17)$ died between 24 and $48 \mathrm{~h}$ exposure. The mortalities occurred after $26 \mathrm{~h}$ (3 fish), $28 \mathrm{~h}(1)$, $30 \mathrm{~h} \mathrm{(2),} 36 \mathrm{~h} \mathrm{(2)}$ and $40 \mathrm{~h}$ (1). The mean TW (305 \pm $32.1 \mathrm{~g})$ and TL $(24.7 \pm 1.0 \mathrm{~cm})$ of surviving fish were significantly smaller $(P<0.05)$ than that of the fish that died $(425.1 \pm 33.1 \mathrm{~g} ; 28.7 \pm 0.8 \mathrm{~cm}$; see Table 1 and Fig. 2).

During the hypoxia trials two distinct behaviour patterns were observed. Fish that survived in the $1 \mathrm{ml} / \mathrm{l}$

Table 1. The mean total length (TL, cm) and total weight (TW, g) of male and female Rhabdosargus sarba used in control and hypoxia treatments. Mean TL and TW of fish that died during the $48 \mathrm{~h}, 1 \mathrm{ml} / 1 \mathrm{DO}$ treatment are also shown. Sample sizes are in parenthesis.

\begin{tabular}{|c|c|c|c|c|c|c|c|c|c|c|}
\hline & \multicolumn{2}{|c|}{ All fish } & \multicolumn{2}{|c|}{$\begin{array}{c}\text { Female } \\
\text { survivors }\end{array}$} & \multicolumn{2}{|c|}{$\begin{array}{c}\text { Male } \\
\text { survivors }\end{array}$} & \multicolumn{2}{|c|}{$\begin{array}{c}\text { Female } \\
\text { mortalities }\end{array}$} & \multicolumn{2}{|c|}{$\begin{array}{c}\text { Male } \\
\text { mortalities }\end{array}$} \\
\hline & $\begin{array}{l}\text { TW } \\
(\mathrm{g})\end{array}$ & $\begin{array}{c}\text { TL } \\
(\mathrm{cm})\end{array}$ & $\begin{array}{l}\text { TW } \\
\text { (g) }\end{array}$ & $\begin{array}{c}\text { TL } \\
(\mathrm{cm})\end{array}$ & $\begin{array}{l}\text { TW } \\
\text { (g) }\end{array}$ & $\begin{array}{c}\text { TL } \\
(\mathrm{cm})\end{array}$ & $\begin{array}{l}\text { TW } \\
\text { (g) }\end{array}$ & $\begin{array}{c}\mathrm{TL} \\
(\mathrm{cm})\end{array}$ & $\begin{array}{l}\text { TW } \\
\text { (g) }\end{array}$ & $\begin{array}{c}\mathrm{TL} \\
(\mathrm{cm})\end{array}$ \\
\hline Control & $\begin{array}{c}301.2 \\
(16)\end{array}$ & $\begin{array}{l}24.8 \\
(16)\end{array}$ & $\begin{array}{c}355.9 \\
(10)\end{array}$ & $\begin{array}{l}26.3 \\
(10)\end{array}$ & $\begin{array}{c}210.2 \\
(6)\end{array}$ & $\begin{array}{c}22.3 \\
(6)\end{array}$ & * & $*$ & $*$ & $*$ \\
\hline $\begin{array}{l}\text { Hypoxia } \\
\text { exposed }\end{array}$ & $\begin{array}{c}342.3 \\
(29)\end{array}$ & $\begin{array}{l}25.9 \\
(29)\end{array}$ & $\begin{array}{c}318.6 \\
(14)\end{array}$ & $\begin{array}{l}25.3 \\
(14)\end{array}$ & $\begin{array}{c}273.3 \\
(6)\end{array}$ & $\begin{array}{c}23.4 \\
(6)\end{array}$ & $\begin{array}{c}474.7 \\
(3)\end{array}$ & $\begin{array}{c}29.3 \\
(3)\end{array}$ & $\begin{array}{c}400.3 \\
(6)\end{array}$ & $\begin{array}{c}28.3 \\
(6)\end{array}$ \\
\hline
\end{tabular}

*No control; fish dead. 

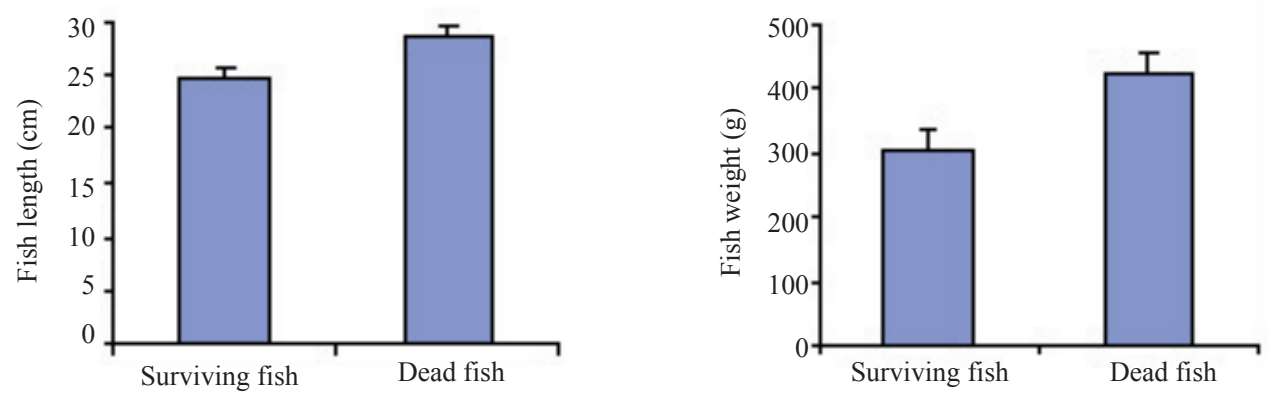

Figure 2. Comparisons of the TL and TW of surviving and non-surviving Rhabdosargus sarba kept at $1 \mathrm{ml} / 1 \mathrm{DO}$ for $48 \mathrm{~h}$. Means and standard errors are shown.

DO trials reduced their routine locomotor activity, and after approximately $20 \mathrm{~h}$ lay almost immobile at the bottom of the tanks, appearing to have increased their ventilation rates. The fish that eventually died swam upwards in the water column, sometimes at burst swimming movement, but thereafter lost their balance and sank to the bottom where they remained inactive until they died.

Plasma $\mathrm{Na}^{+}$concentrations ranged between 148 $\mathrm{mmol} / \mathrm{l}$ in normoxic fish and a maximum of 176.6 $\mathrm{mmol} / \mathrm{l}$ in control fish after 3 hours (Table 2). There were no statistically significant fluctuations in plasma $\mathrm{Na}^{+}$concentrations, irrespective of treatment, exposure time, gender, fish size, or the interactions (Table 3). Likewise, no significant trends could be observed in either $\mathrm{Cl}$ (range 136.8 - $160.8 \mathrm{mmol} / \mathrm{l})$ or $\mathrm{Mg}^{2+}(0.07$ $0.25 \mathrm{mmol} / \mathrm{l}$ ) (Tables 2 and 3 ). The $\mathrm{Ca}^{2+}$ concentrations were not examined at $6 \mathrm{~h}$ and at $24 \mathrm{~h}$ for the $1 \mathrm{ml} / 1 \mathrm{DO}$ treatment because not enough plasma was available for analysis. In the only trial with a positive result, the plasma $\mathrm{Ca}^{2+}$ concentrations were significantly higher in fish exposed to 1 and $2 \mathrm{ml} / 1 \mathrm{DO}$ for $48 \mathrm{~h}$ than their controls. However, given the small sample sizes used for the $\mathrm{Ca}^{2+}$ determinations, and the comparatively low value for the $48 \mathrm{~h}$ control measurement $(0.47$ $\mathrm{mmol} / \mathrm{l})$ relative to the other controls $(0.57-0.65$ $\mathrm{mmol} / \mathrm{l}$; see Table 2), the significant increase seen in $\mathrm{Ca}^{2+}$ after $48 \mathrm{~h}$ at 1 and $2 \mathrm{ml} / 1 \mathrm{DO}$ exposure may be artifactual. Therefore we concluded that none of the plasma electrolytes measured $\left(\mathrm{Na}^{+}, \mathrm{Cl}, \mathrm{Mg}^{2+}\right.$ and $\mathrm{Ca}^{2+}$ ) showed a significant effect relative to exposure of time, treatment, gender, TW or TL, or interactions between the boundaries tested.

\section{Discussion}

The effects of hypoxia on fish behaviour and mortalities have been studied for several species using a variety of DO levels and exposure times, and sensitivity to low oxygen appears to be species dependent, broadly ranging from 0.9 to $2.2 \mathrm{ml} / 1 \mathrm{DO}$ (see Table 4 and Itazawa, 1971; Gee et al., 1978; Van den Thilart and Waarde, 1985). Woo and $\mathrm{Wu}$ (1984) found black seabream Mylio macrocephalus to be at the lower extreme of the sensitivity range (no mortalities at 0.7 $\mathrm{ml} / 1 \mathrm{DO}$ in $7 \mathrm{~h}$ but some deaths at $0.4 \mathrm{ml} / 1 \mathrm{DO}$; Wu and Woo, 1984). Conversely, Atlantic cod Gadus morhua and rainbow trout Oncorhynchus mykiss exhibited higher mortality rates over similar time spans at DO levels $>0.7 \mathrm{ml} / 1$ (Plante et al., 1998) (Table 4). In our study, no $R$. sarba died over a short time span of up to $24 \mathrm{~h}$, even at $1 \mathrm{ml} / 1 \mathrm{DO}$, and it therefore exhibits a relatively high tolerance to hypoxia.

Hypoxia elicits hyperventilation in a variety of marine teleosts (Holeton and Randall, 1967;; Soivio et al., 1980; Soivio et al., 1981; Woo and Wu, 1984; Thomas et al., 1988; Brauner and Randall, 1998; Maxime et al., 2000; Pichavant et al., 2002; Evans et al., 2005), and was also observed in $R$. sarba. The hyperventilation facilitates increased oxygen uptake and enhances convective conditions for $\mathrm{CO}_{2}$ removal (Brauner and Randall, 1998). A reduction in swimming activity as an energy-saving strategy, as reported for flatfish Solea solea (Dalla Via et al., 1998), was also observed for $R$. sarba. However, not all $R$. sarba reduced their swimming activity, with some individuals showing strenuous avoidance behaviour - the latter group with a higher mortality rate. Van Raaij et al. (1996a) reported a five-fold catecholamine elevation after strenuous avoidance behaviour of nonsurviving Oncorhynchus mykiss - this information is unfortunately not available for $R$. sarba.

The $R$. sarba that died during the $48 \mathrm{~h}$ trial at $1 \mathrm{ml} / 1$ DO had a significantly larger mean size (both TL and TW) than those that survived. Smaller individuals of several other fish species were also found to be more 
Al-Gheilani and others

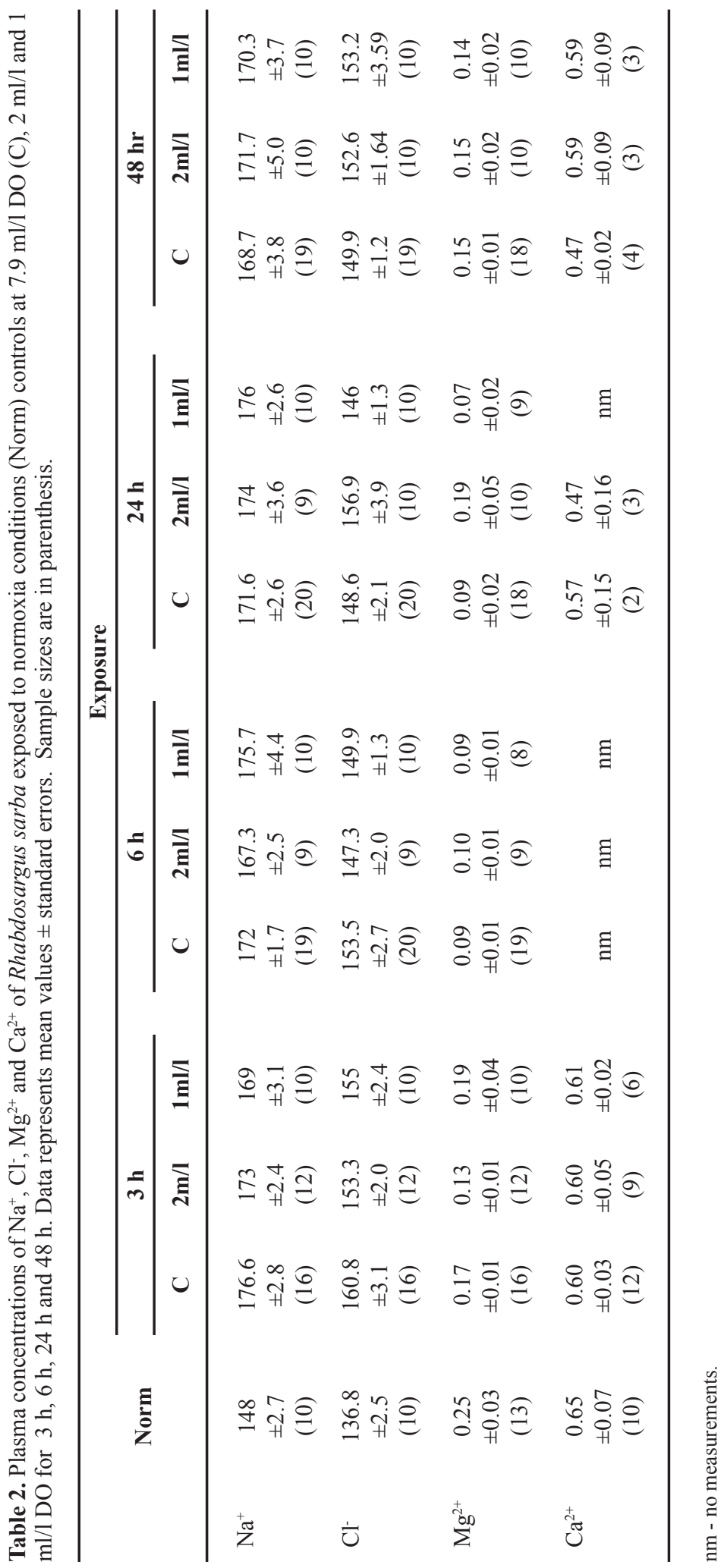


Table 3. The probability matrix $(\alpha=0.05)$ of the effects of treatment $(1 \mathrm{ml} / 1$ and $2 \mathrm{ml} / 1 \mathrm{DO})$, exposure time ( $3 \mathrm{~h}, 6$ $\mathrm{h}, 24 \mathrm{~h}$ and $48 \mathrm{~h}$ ), gender, TW and TL, and the interactions time $\times$ treatment, time $\times$ gender, treatment $\times$ gender and time $\times$ treatment $\times$ gender on plasma electrolyte concentrations of Rhabdosargus sarba.

\begin{tabular}{lccccccccc}
\hline & & TL/TW & $\begin{array}{c}\text { Treat- } \\
\text { ment }\end{array}$ & Time & Gender & $\begin{array}{c}\text { Treat- } \\
\text { ment* } \\
\text { time }\end{array}$ & $\begin{array}{c}\text { Treat- } \\
\text { ment* } \\
\text { Gender }\end{array}$ & $\begin{array}{c}\text { Time* } \\
\text { Gender }\end{array}$ & $\begin{array}{c}\text { Treatment* } \\
\text { Time* } \\
\text { Gender }\end{array}$ \\
\hline $\mathrm{Na}^{+}$ & $\mathrm{TL}$ & 0.816 & 0.645 & 0.949 & 0.614 & 0.231 & 0.261 & 0.866 & 0.084 \\
& $\mathrm{TW}$ & 0.534 & 0.608 & 0.873 & 0.539 & 0.255 & 0.267 & 0.894 & 0.082 \\
$\mathrm{Cl}^{-}$ & & & & & & & & & \\
& $\mathrm{TL}$ & 0.373 & 0.228 & 0.707 & 0.096 & 0.050 & 0.566 & 0.908 & 0.926 \\
$\mathrm{Mg}^{2+}$ & $\mathrm{TW}$ & 0.594 & 0.222 & 0.456 & 0.075 & 0.049 & 0.591 & 0.912 & 0.944 \\
& $\mathrm{TL}$ & 0.749 & 0.522 & 0.816 & 0.505 & 0.866 & 0.553 & 0.749 & 0.893 \\
$\mathrm{Ca}^{2+}$ & $\mathrm{TW}$ & 0.857 & 0.857 & 0.531 & 0.846 & 0.846 & 0.534 & 0.761 & 0.900 \\
& $\mathrm{TL}$ & 0.051 & 0.023 & 0.066 & 0.231 & 0.020 & & & \\
\hline & $\mathrm{TW}$ & 0.044 & 0.027 & 0.052 & 0.299 & 0.020 & & & \\
\hline
\end{tabular}

tolerant of hypoxia than larger fish (Smale and Rabeni, 1995; Burleson et al., 2001; Robb and Abrahams, 2003). The higher mortality rates of larger fish may be related to lower size-surface; body weight ratios in larger individuals.
Timmerman and Chapman (2004) studied the effect of hypoxia on behavioural and physiological responses of sailfin Poecilia latipinna and concluded that females were more tolerant to hypoxia than males. Overli et al. (2006) reported that male fish were more

Table 4. The effects of hypoxia on fish mortality rates from studies at a range of exposure times and DO levels.

\begin{tabular}{|c|c|c|c|c|}
\hline Species & $\begin{array}{l}\text { DO } \\
(\mathrm{ml} / \mathrm{l})\end{array}$ & $\begin{array}{c}\text { Exposure } \\
\text { time }\end{array}$ & $\begin{array}{l}\text { Mortalities } \\
\text { (\%) }\end{array}$ & Reference \\
\hline Solea solea & $\begin{array}{l}0.3 \\
0.5\end{array}$ & $\begin{array}{l}12 \mathrm{~h} \\
12 \mathrm{~h}\end{array}$ & $\begin{array}{l}0 \\
0\end{array}$ & Dalla Via et al., 1994 \\
\hline $\begin{array}{l}\text { Scophthalmus maximus } \\
\text { Dicentrarchus labrax }\end{array}$ & 1.7 & 40 days & 0 & Pichavant et al., 2003 \\
\hline $\begin{array}{l}\text { Epinephelus akaara Mylio } \\
\text { macrocephalus }\end{array}$ & 0.7 & $7 \mathrm{~h}$ & 0 & Woo and Wu, 1984 \\
\hline $\begin{array}{l}\text { Epinephelus akaara Mylio } \\
\text { macrocephalus }\end{array}$ & 0.4 & $7 \mathrm{~h}$ & Few & Wu and Woo, 1984 \\
\hline Gadus morhua & $\begin{array}{l}0.4 \\
0.7 \\
1.5\end{array}$ & $\begin{array}{l}7 \mathrm{~h} \\
7 \mathrm{~h} \\
7 \mathrm{~h}\end{array}$ & $\begin{array}{c}100 \\
\text { Most } \\
0\end{array}$ & Plante et al., 1998 \\
\hline Scophthalmus maximus & 1.3 & $6 \mathrm{~h}$ & 0 & Pichavant et al, 2002 \\
\hline Oncorhynchus mykiss & 1.5 & $3 \mathrm{~h}$ & 40 & Van Raaij et al., 1996a \\
\hline Gadus morhua & 1.3 & $6 \mathrm{~h}$ & 21 & Claireaux and Dutil, 1992 \\
\hline
\end{tabular}


Table 5. The effects of hypoxia exposure on plasma electrolyte concentrations of selected fish species from the literature. No effect $=0 ;+=$ increase; $-=$ decrease.

\begin{tabular}{|c|c|c|c|c|c|c|c|}
\hline Species & $\begin{array}{c}\mathrm{DO} \\
\mathrm{ml} / \mathrm{I})\end{array}$ & $\underset{\text { time }}{\operatorname{Exp}}$ & $\mathbf{N a}^{+}$ & $\mathrm{Cl}^{-}$ & $\mathrm{Ca}^{2+}$ & $\mathbf{M g}^{2+}$ & Reference \\
\hline O. mykiss & 1.5 & $12 \mathrm{~h}$ & 0 & 0 & & & (Van Raaij et al., 1996b) \\
\hline Cyprinus carpio* & 0.5 & $30 \mathrm{~m}$ & 0 & 0 & & & (Fuchs and Albers, 1988) \\
\hline Acipenser baeri & 0.4 & $30 \mathrm{~m}$ & 0 & 0 & & & (Maxime et al., 1995) \\
\hline Cyprinus carpio & 1.5 & $24 \mathrm{~h}$ & 0 & 0 & 0 & + & (Kakuta et al., 1992) \\
\hline O. mykiss & 4 & $3 \mathrm{~h}$ & + & - & - & - & (Soivio et al., 1981) \\
\hline Mylio macrocephalus & 0.7 & $7 \mathrm{~h}$ & + & & 0 & & (Woo and Wu, 1984) \\
\hline Scophthalmus maximus & $\begin{array}{l}2.5 \\
3.5\end{array}$ & $\begin{array}{c}45 \\
\text { days }\end{array}$ & 0 & 0 & & & (Pichavant et al., 2000) \\
\hline
\end{tabular}

*Hypercapnic and hypoxia stress.

aggressive than females, and would presumably consume more oxygen. In the present study a larger proportion of males than females died in the $1 \mathrm{ml} / \mathrm{l}$ treatment for $48 \mathrm{~h}$, and although the sample size was small (12 males and 17 females), we suggest that female $R$. sarba may be more tolerant to hypoxia than males.

The absence of significant fluctuations in plasma electrolytes $\left(\mathrm{Na}^{+}, \mathrm{Cl}^{-}, \mathrm{Mg}^{2+}\right.$ and $\left.\mathrm{Ca}^{2+}\right)$ of $R$. sarba during hypoxia exposure is in accordance with the results of several other studies on marine teleosts (see Table 5), where positive results were only sporadically found. Woo and $\mathrm{Wu}$ (1984) studied the effect of hypoxia on $\mathrm{Ca}^{2+}$ and $\mathrm{Na}^{+}$serum levels in $M$. macrocephalus, and found $\mathrm{Ca}^{2+}$ levels to be unchanged whilst $\mathrm{Na}^{+}$increased. They attributed the $\mathrm{Na}^{+}$elevation to impairment of branchial or renal functions. The decrease of $\mathrm{Mg}^{2+}$ reported by Kakuta et al. (1992) in Cyprinus carpio was attributed to a selective gain of ions entering the fish from a hyperionic environment. Most other studies could not, however, find a relationship between hypoxic conditions and fluctuations in plasma electrolytes (Table 5).

The effects of netting (or capture) stress, confinement, transport, exercise and air-exposure on marine teleost electrolyte balance have often been reported upon, and the causes for imbalances have been suggested in some cases. Railo et al., (1985) reported rapid changes in the plasma electrolyte composition of even mildly stressed fish, which suggests that capture stress had profound effects on salt and water balance. Imbalances in plasma $\mathrm{Na}^{+} / \mathrm{Cl}^{-}$ratio may reflect disturbed acid-base regulation (McDonald and Wood,
1993; Mazon et al., 2002), or increasing membrane permeability due to disruption of the membrane integrity of gill cells (Stagg and Shuttleworth, 1982; McDonald and Wood, 1993). Ionregulatory disruption induced by copper was related to inhibition of branchial $\mathrm{Na}^{+}-\mathrm{K}^{+}$-ATPase activity (Lauren and McDonald, 1985; Pelgrom et al., 1995). Knudsen and Jensen (1998) reported on exercise-induced hyperkalaemia as a consequence of an efflux of $\mathrm{K}^{+}$from skeletal muscles during their depolarization and an insufficient reuptake. Farrell (1984) suggested that elevated plasma $\mathrm{Ca}^{2+}$ and catecholamine levels protect the teleostean heart from acidosis which might result from stress. Salm et al. (2006) found that the plasma $\mathrm{Na}^{+}$ levels in Pagrus pagrus increased upon netting stress, but that other plasma ions remained unchanged, and suggested a selective gain of ions from a hyperionic environment. After 2 hours of netting stress, all plasma ion levels returned to, or dropped below basal control levels, suggesting that gill permeability had returned to normal and hydromineral balance restored.

\section{Acknowledgements}

Special Thanks for Dr. Johan for his reviewing of this paper and adding of valid ideas and corrections. This project was funded by Ministry of Fisheries Wealth and Sultan Qaboos University.

\section{References}

Al Busaidi, S.S., K.M. Al Rashdi, H.M. Al Gheilani, and S. Amer. 2007. Massive fish mortality during 
red tide of Masirah Island, Arabian Sea. This Issue.

Al Gheilani, H.M., A.Y.A. Al Kindi, S. Amer, and Y.K. Al-Akhzami. Red tides and harmful algal blooms in coastal waters of Oman (to be submitted).

Al Gheilani, H.M. 2007. Physiological and biochemical effects of hypoxia exposure on goldlined seabream, Rhabdosargus sarba. Ph.D. Thesis. Portsmouth University, UK.

Brauner, C.J. and D.J. Randall. 1998. The linkage between oxygen and carbon dioxide transport. Fish Physiology, 17:283-319.

Burleson, M.L., D.R. Wilhelm, and N.J. Smatresk. 2001. The influence of fish size on the avoidance of hypoxia and oxygen selection by largemouth bass. Journal of Fish Biology, 59:1336-1349.

Claereboudt, M., G. Hermosa, and G. McLean. 2001. Plausible cause of massive fish kills in the Gulf of Oman. In: First International Conference on Fisheries, Aquaculture and Environment in the NW Indian Ocean. M. Claereboudt, S. Goddard, H. Al-Oufi, and J. McIlwain (Editors), pp.123-132. Sultan Qaboos University, Muscat, Sultanate of Oman.

Dalla Via, J., G. Van Den Thillart, O. Cattani, and A. De Zewaan. 1994. Influence of long-term hypoxia exposure on the energy metabolism of Solea solea. II Intermediary metabolism in blood, liver and muscle. Marine Ecology Progress Series, 111: 17-27.

Dalla Via, J., P. Villan, E. Gasteiger, and H. Niederstatter. 1998. Oxygen consumption in sea bass fingerling Dicentrarchus labrax exposed to acute salinity and temperature changes: metabolic basis for maximum stocking density estimations. Aquaculture 167: 303-13.

Evans, D.H. P.M. Piermarini, and K.P. Choe. 2005. The multifunctional fish gill: dominant site of gas exchange, osmoregulation, acid-base regulation, and excretion of nitrogenous waste. Physiological Review, 85:97-177.

Farrell, A.P. 1984. A review of cardiac performance in the teleost heart: intrinsic and humoral regulation. Canadian Journal of Zoology, 62:523-536.

Fletcher, G.L. 1975. The effects of capture, stress and storage of whole blood cells, plasma proteins, glucose and electrolytes of winter flounder, Pseudopleuronectes americanus. Canadian Journal of Zoology, 53: 97-206.

Gee, J.H., R.F. Tallman, and H.J. Smart. 1978. Reactions of some great plain fishes to progressive hypoxia. Canadian Journal of Zoology, 56:19621966.
Hishida, Y., A. Ishimatsu, and T. Oda. 1999. Effect of environmental hypoxia on respiration of yellow exposed to Chattenolla marina. Fisheries Science, 65(1):84-90.

Holeton, G.F. and D.J. Randall. 1967. The effects of hypoxia upon the partial pressure of gases in the blood and water afferent and efferent on the gills of rainbow. Journal of Experimental Biology, 227: 339-348.

Itazawa, Y. 1971. An estimation of the minimum level of dissolved oxygen in water required for normal life of fish. Bulletin Japan Society Science Fish, 37:273-276.

Kakuta, I., K. Namba, K. Uematsu, and S. Murachi, S. 1992. Effects of hypoxia on rental functions in carp, Cyprinus carpio. Comparative Biology and Physiology, 101A (4):769-774.

Kinkead, R. and S.F. Perry. 1991. The effects of intraarterial infusion of catecholamines on ventilation in rainbow trout (Oncorhynchus mykiss) exposed to external hypoxia or hypercapina. Respiratory Physiology, 84:77-92.

Knudsen, P.K. and F.B. Jensen. 1998. Effects of exhausting exercise and catecholamines on $\mathrm{K}^{+}$ balance acid-base status and blood respiratory properties in carp. Comparative Biochemistry and Physiology, 119A:301-307.

Kramer, D.L. 1987. Dissolved oxygen ad fish behaviour. Environmental Biology of Fishes, 7: 81-92.

Lapner, K.N. and S.F. Perry. 2001. The role of angiotensin II in regulating catecholamine secretion during hypoxia in rainbow trout Oncorhynchus mykiss. Journal of Experimental Biology, 204: 4169-4176.

Lauren, D.J., and D.G. McDonald. 1985. Effects of copper on branchial ionoregulation in the rainbow trout, Oncorhynchus mykiss. Modulation by water hardness and $\mathrm{pH}$. Journal of Comparative Physiology B, 155:635-644.

Maxime, V., K. Pichavant, G. Boeut, and G. Nonnotte. 2000. Effects of hypoxia on respiratory physiology of turbot, Scophthalmus maximus. Fish Physiology and Biochemistry, 22:51-59.

Mazon, A.F., C.C.C. Cerqueira, and M.N. Fernnandes. 2002. Gill cellular changes induced by copper exposure in the South American tropical freshwater fish, Prochilodus scrofa. Environmental Research, 88A:52-63.

McDonald, D.G. and C.M. Wood. 1993. Branchial Acclimation to Metals. In: Fish Ecophysiology. J.C. Rankin and F.B. Jensen (Editors), pp. 297-321. Chapman and Hall, London. 
Overli, O., C. Sorensen, and G. Nilsson. 2006. Behavioural indicators of stress-coping style in rainbow trout: Do males and females react differently to novelty? Physiology and Behaviour, 87:507-512.

Pawson, M.G. and S.J. Lockwood. 1980. Mortality of mackerel following physical stress, and its probable cause. Papports et Proces-Verbaux des Reunions, Conseil International pour Exploration dela Mer, 177:439-443.

Pelgrom, S.M., R.A.C. Lock, P.H.M. Balm, and S.E. Wendelaar Bonga. 1995. Integrated physiological response of tilapia, Oreochromis mossamicus, to sublethal copper exposure. Aquatic Toxicology, 32:302-320.

Perry, S.F., S.G. Reid, K.M. Gilmour, C.L. Boijink, J.M. Lopes, W.K. Milsom, and F.T. Rantin. 2004. A comparison of adrenergic stress responses in three tropical teleosts exposed to acute hypoxia. American Journal of Physiology - Regulatory, Integrative, Comparative, Physiology, 287:R188R197.

Pichavant, K., V. Maxime, M.T. Thebault, H. Ollivier, and J.P. Garnier. 2002. Effects of hypoxia and subsequent recovery on turbot Scophthalmus maximus: hormonal changes and anaerobic metabolism. Marine Ecology Progress Series, 225: 275-285.

Plante, S., D. Chabot, and J.D. Dutil. 1998. Hypoxia tolerance in Atlantic cod. Journal of Fish Biology, 53:1342-56.

Railo, E., M. Nikinmaa, and A. Soivio. 1985. Effects of sampling on blood parameters in the rainbow trout Oncorhynchus mykiss. Journal of Fish Biology, 26:725-732.

Randall, D.J. 1990. Control and co-ordination of gas exchange in water breathers. Advances in Comparative and Environmental Physiology, 6: 253-278.

Randall, J.E. 1995. Coastal Fishes of Oman. University of Hawaii Press.

Robb, T. and M.V. Abrahams. 2003. Variation in tolerance to hypoxia in a predator and prey species; an ecological advantage of being small? Journal of Fish Biology, 62: 1067-1081.

Robenston, L., P. Thomas, C.R. Arnold, and J.M. Trant. 1987. Plasma cortisol and secondary stress responses of red drum to handling transport, rearing density and a disease outbreak. Progressive Fish-Culturist, 49(1):1-12.

Salm, A.L., M. Pavlidis, G. Flik, and S.E. Wendelaar Bonga. 2006. The acute stress response of red porgy, Pagrus pagrus, kept on a red or white background.
General and Comparative Endocrinology, 145: 247-253.

Smale, M.A. and C.F. Rabeni. 1995. Hypoxia and hypothermia tolerances of headwater stream fishes. Transaction of the American Fisheries Society, 124:698-710.

Smith, F.M. and D.R. Jones. 1982. The effect of changes in blood oxygen-carrying capacity on ventilation volume in the rainbow trout Oncorhynchus mykiss. Journal of Experimental Biology, 97:325-334.

Soivio, A., M. Nikinmaa, and K. Westman. 1980. The blood oxygen binding properties of hypoxic Oncorhynchus mykiss. Journal of Comparative Physiology B, 136:83-87.

Soivio, A., M. Nikinmaa, K. Nyholm, and K. Westman. 1981. The role of gills in the responses of Oncorhynchus mykiss during moderate hypoxia. Comparative Biochemistry and Physiology, 70A: 133-139.

Stagg, R.M. and T.J. Shuttleworth. 1982. The effects of copper on ionic regulation by the gills of the seawater-adapted flounder (Platichthys flesus L.). Journal of Comparative Physiology, 149:83-90.

Strickland, J. and T. Parsons. 1972. A Practical Handbook of Sea Water Analysis. Fisheries Research Board of Canada, Ottawa, Canada.

Thomas, S., B. Fievet, and R. Motais. 1988. Adaptive respiratory responses of trout to acute hypoxia. I. Effects of water ionic composition on blood acidbase responses and gill morphology. Respiratory Physiology, 74:77-90.

Timmerman, C.M. and L.J. Chapman. 2004. Behavioral and physiological compensation for chronic hypoxia in the sailfin molly (Poecilia latipinna). Physiological and Biochemical Zoology, 77(4): 601-610.

Van Raaij, M.T.M., D.S.S. Pit, P.H.M. Balm, A.B. Steffens, G. Van den Thillart, and J.H. Gee. 1996a. Behavioural strategy and the Physiological Stress Response in Rainbow Trout Exposed to Severe Hypoxia. Hormones and Behaviour, 30:85-92.

Van Raaij, M.T.M., G.J. Vianen, G. Van den Thillart, and J.H. Gee. 1996b. Blood gas parameters and the responses of erythrocytes in carp exposed to deep hypoxia and subsequent recovery. Journal of Comparative Physiology B, 166:453-460.

Van Waversveld, J., A.D.F. Addink, and G. Van den Thillart. 1989. The anaerobic energy metabolism of goldfish determined by simultaneous direct and indirect calorimetry during anoxia and hypoxia. Journal of Comparative Physiology, 159:263-268. 
Waring, C.P., R.M. Stagg, and M.G. Poxon. 1992. The effects of handling on flounder (Platichys flesus L.) and Atlantic salmon (Salmo salar L.). Journal of Fish Biology, 41:131-144.

Waring, C.P., R.M. Stagg, and M.G. Poxon. 1996. Physiological responses to handling in the turbot. Journal of Fish Biology, 48:161-173.
Woo, N.Y.S. and R.S.S. Wu. 1984. Changes in biochemical composition in the red grouper, Epinephelus akaara (Temminck and Schlegel), and the black seabream, Mylio macrocephalus (Basilwsky), during hypoxic exposure. Comparative Biochemistry and Physiology, 77A(3): 475-482. 